\title{
Destruction assessment of wind power plastics blade
}

\author{
Jozef Flizikowski ${ }^{1) *}{ }^{*}$, Izabela Piasecka ${ }^{1)}$, Weronika Kruszelnicka ${ }^{1)}$, Andrzej Tomporowski ${ }^{11}$, \\ Adam Mroziński ${ }^{1)}$
}

DOI: dx.doi.org/10.14314/polimery.2018.5.7

\begin{abstract}
The study resulted in testing and assessment procedure for destructiveness of Gamesa G90 wind power rotor plastics blades of their life cycle. The achieved goal embraced ergonomic, functional, ecological and technological destructiveness. The life cycle comprises stages from design to disposal. The best results connected with ergonomic, functional, ecological and technological destructiveness of the disposal model in the form of recycling were obtained for the life processes of plastics related to fossil fuel extraction $\left(-2.56 \cdot 10^{5} \mathrm{MJ}\right)$.
\end{abstract}

Keywords: life cycle assessment, Eco-indicator 99, polymer materials, wind turbine.

\section{Ocena destrukcyjności polimerowych łopat elektrowni wiatrowych}

Streszczenie: Zaproponowano procedurę badań i oceny destrukcyjności łopat wirnika elektrowni wiatrowej Gamesa G90. Przyjęto cztery przestrzenie destrukcyjnego oddziaływania: stanowisko pracy operatorów - destrukcyjność ergonomiczna, dokładność realizacji funkcji siłowni - funkcjonalna, środowisko organizmów żywych - ekologiczna, urządzenia, maszyny, instalacje - technologiczna. Analizowany cykl życia obejmował etapy od wykonania projektu do zagospodarowania poużytkowego łopat wykonanych z tworzyw polimerowych. Najwyraźniejsze zmniejszenie poziomu destrukcyjnego oddziaływania podczas wytwarzania, eksploatacji i recyklingu łopat wirnika elektrowni wiatrowej stwierdzono w odniesieniu do procesów związanych z wydobyciem paliw kopalnych $\left(-2,56 \cdot 10^{5} \mathrm{MJ}\right)$.

Słowa kluczowe: ocena cyklu życia, Eko-wskaźnik 99, materiały polimerowe, łopaty turbin wiatrowych.

Energy and activity are the main factors of economic development and improvement of life quality. Conversion of primary energy into more refined types, especially electrical energy, has beneficial and destructive impacts on human health, energy supply security, and environment [1].

The increase in the share of alternative energy sources in the Polish fuel and energy balance lets us achieve a range of benefits in terms of sustainable environmental development and reduction of harmful gases and solid particles emission, which results in lower greenhouse effect and improved condition of the environment. Reduced extraction and use of fossil fuels are beneficial for keeping the natural state of flora and fauna, as well as inanimate nature [2].

The processes from resource extraction, through plastics processing, to wind turbine blade manufacture involve complex relationships: natural environment - management system and natural environment - management effects, which are the focus of many fields of both science and practice. However, there is a lack of all-embracing

\footnotetext{
1) University of Live Sciences and Technology in Bydgoszcz, Faculty of Mechanical Engineering, Al. prof. S. Kaliskiego 7, 85-796 Bydgoszcz, Poland.

*) Author for correspondence; e-mail: fliz@utp.edu.pl
}

system wide procedures and assessments, which would make it possible to assess objectively the destructive impact of wind turbine blades, taking into account their life cycle and all the stages of their existence [3,4].

This has become the basis for search for testing procedures and assessments, and the goal of this study, which objectifies constructive and destructive interactions that occur at all stages of wind turbine blades' life cycle. The blades are most problematic when it comes to disposal because of their complex composite structure $[5,6]$.

The main goal was to design and create the new methodology for testing and destructions assessment of wind turbine rotor plastics blades, with the emphasis on environmental aspects.

\section{METHODOLOGY OF DESTRUCTION ASSESSMENT}

Life of every wind turbine blade is made up of five main phases: demand, design, manufacture, use, and disposal. In each of these phases appropriate systems are to perform a separate activity in order to achieve a desired effect [7].

We use a characterization called system destructiveness as an object of the procedure, testing methodology, life cycle assessment and indication of the level of 
harmful impact on the environment. In order to define the detailed destructiveness characterization, we need to identify and divide the environment into separate components and relations between them. We may isolate:

- operators (persons that operate the wind turbine or are constantly present near it);

- workpiece (wind and the part of the environment which is affected by the plastic blade, according to its purpose);

- living objects of the environment (elements of natural environment near the wind blades turbine);

- artificial objects of the environment (technical infrastructure and any human-made objects near the blades).

As the above named environmental elements differ from each other, there is a need for defining adequate indicators of variables and destructiveness characterization, which will include sensitivity of single environmental elements:

- ergonomic destructiveness expresses the extent of destructive impact of the wind turbine blades on its operator;

- functional destructiveness symbolizes the extent of negative impact on the workpiece or losses that occur during its operation;

- ecological destructiveness represents the characterization of harmful, but unintentional influence on living objects of the environment;

- technological destructiveness includes many elements. It often describes destructiveness from a very wide perspective, without isolating specific objects it is focused on. In reference to rotor blades, environmental destructiveness indicates the degree of harmful impact on artificial objects of the technology environment, meaning everything made by humans, using processed or natural raw materials $[1,8]$.

The balance sheet of harmful streams of information, energy and matter emitted by wind turbine plastic blades states that the magnitude of negative impacts depends on the stream of loss (S). Through analogy to effectiveness from the point of view of hazards, destructiveness $(D)$ may be formally defined as a quotient of losses $(S)$ and outlays $(N)[9]$ :

$$
D=\frac{S}{N}
$$

Destructiveness indicators may serve as hazard measures (also through analogy to effectiveness). They are created by establishing the set of variables:

$$
X=\left\{X_{k} ; k=\overline{1, K}\right\}
$$

where: $X_{1}=S$ (losses), $X_{2}=T$ (time), $X_{3}=G$ (object characterization), $X_{4}=N$ (outlays).

The next step involves establishing the set of variables for each $X_{k}$ element and defining a variable and $K^{2}(I+1)^{2}$ quotients:

$$
\begin{gathered}
X_{k}=\left\{X_{k i} ; i=\overline{1, I}\right\} \\
X_{k, I+1}=\sum_{1}^{l} X_{k i} \\
p_{i j}^{k l}=\frac{X_{k i}}{X_{l j}}
\end{gathered}
$$

where: $k, l=1 \ldots K ; i, j=1 \ldots(I+1)$.

The next step involves arranging $p_{i j}^{k l}$ indicators according to $k, l, i, j$ indexes and putting them together in block matrixes:

$$
p^{k l}=\left[\begin{array}{ll}
{\left[B^{k l}\right]} & {\left[V^{k l}\right]} \\
{\left[H^{k l}\right]} & {\left[a^{k l}\right]}
\end{array}\right]
$$

where: $p$ - matrix of $p_{i j}^{k l}$ destructiveness indicators; $B^{k l}$ specific indicators; $V^{k l}, H^{k l}$ - main indicators; $a^{k l}$ - general indicators $[1,9]$.

\section{Testing objects}

The objects of the detailed procedure of life cycle testing and destructions assessment were Gamesa G90 wind turbine rotor plastics blades. Gamesa G90 is a $2 \mathrm{MW}$ three-blade land-based wind turbine. Rotor diameter is $90 \mathrm{~m}$. Blades are $44 \mathrm{~m}$ long and are made of epoxy resin reinforced with glass fiber (with prepreg molding technology). Outer laminated shells are supported by a spar cap, serving as the central spine of the blade. Reinforcements are $75 \%$ E-glass by weight, infused with epoxy resin. Blades are molded in halves, then joined using an epoxy adhesive. Glass fiber reinforcements are laid in the mold as dry stacks by hand. Structural foam are used as cores in blade construction to support the outer blade shells. Prepreg tapes consist of fiber fabrics pre-impregnated with a resin that is not fully cured. The prepregs are laid up onto the mold surface, vacuum bagged and then heated. The pressure required to consolidate the stacked layers of prepregs is achieved by vacuum. Process temperatures range between $70^{\circ} \mathrm{C}$ and $120^{\circ} \mathrm{C}[7,10]$.

For the purposes of the destruction testing, Life Cycle Assessment (LCA) method was chosen. LCA provides a comprehensive approach to life cycle issues, taking into account all spheres of the life cycle and each type of destructive impact that can occur during the life cycle. Environmental effects and destructive impacts are represented as numbers, which allows the identification of the dominant spheres of the life cycle of wind turbine blades. Although LCA is not the only technology for environmental management, it has many characteristic features that determine its advantages, such as "cradle-to-grave" perspective, which does not omit any stage of the life cycle of the wind turbine rotor blades. The method takes into account all ecosystems and their elements, which allows making comprehensive assessment of rotor blades' destructive impact on environment and assessment of environmental resources consumption [11, 12]. 
T a b l e 1. Division of environmental impact categories taken for analysis (own work)

\begin{tabular}{|c|c|c|}
\hline $\begin{array}{c}\text { Type of } \\
\text { destructiveness }\end{array}$ & $\begin{array}{c}\text { Impact categories } \\
\text { (environmental impacts) }\end{array}$ & Unit \\
\hline \multirow{8}{*}{$\begin{array}{l}\text { Ergonomic } \\
\text { destructiveness }\end{array}$} & $\begin{array}{l}\text { Inorganic compounds causing } \\
\text { respiratory diseases }\end{array}$ & DALY \\
\hline & $\begin{array}{l}\text { Organic compounds causing } \\
\text { respiratory diseases }\end{array}$ & DALY \\
\hline & Radioactive compounds & DALY \\
\hline & Carcinogenic compounds & DALY \\
\hline & Ecotoxic compounds & $\mathrm{PAF} \cdot \mathrm{m}^{2} / \mathrm{a}$ \\
\hline & Land use & $\mathrm{PDF} \cdot \mathrm{m}^{2} / \mathrm{a}$ \\
\hline & Mineral extraction & MJ \\
\hline & Fossil fuels extraction & MJ \\
\hline \multirow{4}{*}{$\begin{array}{l}\text { Functional } \\
\text { destructiveness }\end{array}$} & Radioactive compounds & DALY \\
\hline & Land use & $\mathrm{PDF} \cdot \mathrm{m}^{2} / \mathrm{a}$ \\
\hline & Minerals extraction & MJ \\
\hline & Fossil fuels extraction & MJ \\
\hline \multirow{8}{*}{$\begin{array}{l}\text { Ecological } \\
\text { destructiveness }\end{array}$} & Radioactive compounds & DALY \\
\hline & Ecotoxic compounds & $\mathrm{PAF} \cdot \mathrm{m}^{2} / \mathrm{a}$ \\
\hline & $\begin{array}{l}\text { Compounds causing } \\
\text { acidification/eutrophication }\end{array}$ & $\mathrm{PDF} \cdot \mathrm{m}^{2} / \mathrm{a}$ \\
\hline & $\begin{array}{l}\text { Compounds causing climate } \\
\text { change }\end{array}$ & DALY \\
\hline & $\begin{array}{c}\text { Compounds causing ozone layer } \\
\text { depletion }\end{array}$ & DALY \\
\hline & Land use & $\mathrm{PDF} \cdot \mathrm{m}^{2} / \mathrm{a}$ \\
\hline & Minerals extraction & MJ \\
\hline & Fossil fuels extraction & MJ \\
\hline \multirow{5}{*}{$\begin{array}{l}\text { Technological } \\
\text { destructiveness }\end{array}$} & $\begin{array}{l}\text { Intensity of the use of technical } \\
\text { potential }\end{array}$ & $\mathrm{m}^{3} / \mathrm{a} \cdot \mathrm{MW}$ \\
\hline & Radioactive compounds & DALY \\
\hline & Land use & $\mathrm{PDF} \cdot \mathrm{m}^{2} / \mathrm{a}$ \\
\hline & Minerals extraction & MJ \\
\hline & Fossil fuels extraction & MJ \\
\hline
\end{tabular}

The testing comprised manufacture, use and disposal of wind turbine blades. They were performed with LCA method, using Eco-indicator 99 and SimaPro 7.1 software.

The LCA rating method, in accordance with ISO 14000, consisted of four successive basic elements: the definition of the objective and scope, the analysis of a set of inputs and outputs (LCI), impact assessment (LCIA) and interpretation. The entire evaluation was an iterative process, distinguishing multiple feedback loops. Each and every analytical phase was followed by the operational interpretation of the obtained data. Conducted the analysis may include a bottom-up, and it served mainly the description of the existing reality (retrospective analysis), but also modeling more pro-environmental solutions (prospective analysis). The level of advancement classifies it in detailed analysis. The geographic scope of the analysis is the area of Europe. The time horizon covers a period of 20 years. The data used in the study was obtained from manufacturers or downloaded from the SimaPro database $[13,14]$.

SimaPro program let us assess the destructive impact of rotor plastics blades on the natural environment during a single life cycle. Life cycle of plastics blades consists of three phases: manufacture, use, and disposal. Each phase involved model-based determination of quantity and type of used materials, energy and technological processes applied. With life cycle model designed in such way, the program, using databases attached to it, calculated quantitative destructive impact on environment divided into particular chemical substances. The impact took the form of substances emission or their consumption from the natural environment. Emissions and consumptions were grouped into four impact zones. For emissions, the zones were air, water and soil, while for consumptions raw materials $[15,16]$.

Eco-indicator 99 is used to calculate maximum environmental damage that can occur within Europe. Some of the processes that take place there affect global situation as well. Therefore it is taken into account during the assessment of losses. It includes, among others, damage caused by the depleted ozone layer and greenhouse effect, carcinogenic substances emission and changes in natural resources (on a global scale) [17, 18].

Main assumption of the new testing methodology involved assigning appropriate impact categories of Eco-indicator 99 model to four basic types of destructiveness (Table 1).

\section{RESULTS AND DISCUSSION}

The first step of testing with Eco-indicator 99 method was characterization. Two blade disposal models were applied: waste dump or recycling. Results related to a single life cycle were given for the overall impact of the wind turbine blades (taking into account impact categories). Categories of damages can be captured in the syntactic categories (end points), because they are in each of the groups expressed in the same units. In the category of human health the unit is DALY (Disutility Adjusted Life Years), signifying the number of years of human life survived in illness or at all lost, in the category of environmental quality PDF $\cdot \mathrm{m}^{2} / \mathrm{a}$ or PAF $\cdot \mathrm{m}^{2} / \mathrm{a}$ (where PDF stands for potentially lost parts of plant species and PAF potentially damaged part of these species), in the resource consumption category MJ surplus energy, signifying MJ additional energy needed for the purpose use in the future substitute, inferior quality sources of material or energy supply. Cut-off level amounted to $0.1 \%$ [15].

When it comes to ergonomic destructiveness for the disposal model in the form of waste dump, the highest degree of harmful impact was demonstrated by inorganic compounds causing respiratory diseases (0.0863 DALY), especially sulfur dioxide (53.5\%), ecotoxic compounds (29 570.686 PAF $\left.\cdot \mathrm{m}^{2} / \mathrm{a}\right)$ - especially nickel ( $37.5 \%$ ) and zinc $(22.3 \%)$, land use (3 $\left.013.526 \mathrm{PDF} \cdot \mathrm{m}^{2} / \mathrm{a}\right)$ - mainly 
T a b l e 2. Results of environmental effects characterization for the types of destructiveness occurring during the life cycle of Gamesa G90 wind turbine blades (own work)

\begin{tabular}{|c|c|c|c|}
\hline $\begin{array}{l}\text { Types of } \\
\text { destructive- } \\
\text { ness }\end{array}$ & $\begin{array}{c}\text { Impact categories } \\
\text { (environmental impact) }\end{array}$ & $\begin{array}{l}\text { Waste } \\
\text { dump }\end{array}$ & Recycling \\
\hline \multirow{8}{*}{$\begin{array}{l}\text { Ergonomic } \\
\text { destructive- } \\
\text { ness }\end{array}$} & $\begin{array}{l}\text { Inorganic compounds } \\
\text { causing respiratory } \\
\text { diseases }\end{array}$ & $0.0863^{\mathrm{a}}$ & $-0.0326^{a}$ \\
\hline & $\begin{array}{l}\text { Organic compounds } \\
\text { causing respiratory } \\
\text { diseases }\end{array}$ & $-0.0002^{\mathrm{a}}$ & $-0.000645^{a}$ \\
\hline & Radioactive compounds & $0.0006^{\mathrm{a}}$ & $0^{\mathrm{a}}$ \\
\hline & Carcinogenic compounds & $0.0062^{\mathrm{a}}$ & $0.000879^{\mathrm{a}}$ \\
\hline & Ecotoxic compounds & $29570.686^{\mathrm{b}}$ & $-8.18 \mathrm{E}+03^{\mathrm{b}}$ \\
\hline & Land use & $3013.526^{c}$ & $0^{c}$ \\
\hline & Mineral extraction & $38310.296^{\mathrm{d}}$ & $-2.99 \mathrm{E}+03^{\mathrm{d}}$ \\
\hline & Fossil fuels extraction & $217039.020^{\mathrm{d}}$ & $-2.56 \mathrm{E}+05^{\mathrm{d}}$ \\
\hline \multirow{4}{*}{$\begin{array}{l}\text { Functional } \\
\text { destructive- } \\
\text { ness }\end{array}$} & Radioactive compounds & $0.0006^{\mathrm{a}}$ & $0^{\mathrm{a}}$ \\
\hline & Land use & $3013.526^{c}$ & $0^{c}$ \\
\hline & Minerals extraction & $38310.296^{\mathrm{d}}$ & $-2.99 \mathrm{E}+03^{\mathrm{d}}$ \\
\hline & Fossil fuels extraction & $217039.020^{\mathrm{d}}$ & $-2.56 \mathrm{E}+05^{\mathrm{d}}$ \\
\hline \multirow{8}{*}{$\begin{array}{l}\text { Ecological } \\
\text { destructive- } \\
\text { ness }\end{array}$} & Radioactive compounds & $0.0006^{\mathrm{a}}$ & $0^{\mathrm{a}}$ \\
\hline & Ecotoxic compounds & $29570.686^{\mathrm{b}}$ & $-8.18 \mathrm{E}+03^{\mathrm{b}}$ \\
\hline & $\begin{array}{l}\text { Compounds causing } \\
\text { acidification/ } \\
\text { eutrophication }\end{array}$ & $2251.595^{c}$ & $-1.57 \mathrm{E}+03^{\mathrm{c}}$ \\
\hline & $\begin{array}{l}\text { Compounds causing } \\
\text { climate change }\end{array}$ & $0.0204^{\mathrm{a}}$ & $-0.00831^{a}$ \\
\hline & $\begin{array}{c}\text { Compounds causing ozone } \\
\text { layer depletion }\end{array}$ & $0.0009^{\mathrm{a}}$ & $-2.04 \mathrm{E}-05^{\mathrm{a}}$ \\
\hline & Land use & $3013.526^{c}$ & $0^{c}$ \\
\hline & Minerals extraction & $38310.296^{\mathrm{d}}$ & $-2.99 \mathrm{E}+03^{\mathrm{d}}$ \\
\hline & Fossil fuels extraction & $217039.020^{\mathrm{d}}$ & $-2.56 \mathrm{E}+05^{\mathrm{d}}$ \\
\hline \multirow{5}{*}{$\begin{array}{l}\text { Technologi- } \\
\text { cal destruc- } \\
\text { tiveness }\end{array}$} & $\begin{array}{c}\text { Intensity of blades' wear } \\
\text { and tear }\end{array}$ & $0.000008^{t}$ & $0^{t}$ \\
\hline & Radioactive compounds & $0.0006^{\mathrm{a}}$ & $0^{\mathrm{a}}$ \\
\hline & Land use & $3013.526^{c}$ & $0^{c}$ \\
\hline & Minerals extraction & $38310.296^{\mathrm{d}}$ & $-2.99 \mathrm{E}+03^{\mathrm{d}}$ \\
\hline & Fossil fuels extraction & $217039.020^{\mathrm{d}}$ & $-2.56 \mathrm{E}+05^{\mathrm{d}}$ \\
\hline
\end{tabular}

${ }^{\mathrm{a}}[\mathrm{DALY}],{ }^{\mathrm{b}}\left[\mathrm{PAF} \cdot \mathrm{m}^{2} / \mathrm{a}\right],{ }^{\mathrm{c}}\left[\mathrm{PDF} \cdot \mathrm{m}^{2} / \mathrm{a}\right],{ }^{\mathrm{d}}[\mathrm{MJ}],{ }^{\mathrm{t}}\left[\mathrm{m}^{3} / \mathrm{a} \cdot \mathrm{MW}\right]$

industrial development (33.3\%), and fossil fuels extraction (217 039.020 MJ) - especially petroleum extraction $42.7 \mathrm{MJ} / \mathrm{kg}(40 \%)$. As for ecological destructiveness, the most crucial degree of harmful impact was exerted by compounds causing climate change (0.0204 DALY), ecotoxic compounds (29 570.686 PAF $\cdot \mathrm{m}^{2} / \mathrm{a}$ ), land use (3 $013.526 \mathrm{PDF} \cdot \mathrm{m}^{2} / \mathrm{a}$ ) and fossil fuels extractions (217 039.020 MJ). Analyzing technological destructiveness, the most harmful impact was demonstrated by land use (3 013.526 PDF $\left.\cdot \mathrm{m}^{2} / \mathrm{a}\right)$ and fossil fuels extraction (217 039.020 MJ) (Table 2).
Assessing ergonomic destructiveness for the disposal model in the form of recycling, the best results of reducing the harmful impact were obtained for the processes related to fossil fuels extraction $\left(-2.56 \cdot 10^{5} \mathrm{MJ}\right)$, ecotoxic compounds $\left(-8.18 \cdot 10^{3} \mathrm{PAF} \cdot \mathrm{m}^{2} / \mathrm{a}\right)$, and inorganic compounds causing respiratory diseases $(-0.0326$ DALY). When it comes to functional destructiveness, the highest reduction of negative impact was recorded for the processes related to fossil fuels extraction $\left(-2.56 \cdot 10^{5} \mathrm{MJ}\right)$. With regard to ecological destructiveness, the most crucial reduction of negative impact was recorded in the processes related to fossil fuels extraction $\left(-2.56 \cdot 10^{5} \mathrm{MJ}\right)$, ecotoxic compounds $\left(-8.18 \cdot 10^{3} \mathrm{PAF} \cdot \mathrm{m}^{2} / \mathrm{a}\right)$, and compounds causing climate change (-0.00831 DALY). Analyzing the degree of technological destructiveness, the harmful impact of the processes related to fossil fuels extraction $\left(-2.56 \cdot 10^{5} \mathrm{MJ}\right)$ and minerals $\left(-2.99 \cdot 10^{3} \mathrm{MJ}\right)$ were reduced to the largest extent (Table 2).

The last stage of LCA analysis was grouping and weighing. The stage resulted in environmental factors expressed in environmental points $(\mathrm{Pt})$, which are aggregate units that allow comparing ecobalance results. A thousand environmental points equal the impact on environment of a single average European citizen in a year. The obtained results were presented separately for overall impact, values of harmful emissions to atmosphere, water, and soil, as well as hazardous impact of polymers [poly(vinyl chloride), polymer environmental resins, polyesters, polyurethanes, epoxy resins, glass and carbon fibers, laminates], metals (cast iron, aluminum, steel, copper), and other plastics and materials (rubber, grease, oil).

Analyzing the overall life cycle impact, we may note that ergonomic destructiveness is characterized by the highest degree of harmful impact for the disposal model in the form of waste dump (8 $962.347 \mathrm{Pt}$ ), whereas functional and technological destructivenesses are characterized by the lowest degree (6 327.289 Pt each). However, ergonomic destructiveness is characterized by the highest degree of harmful impact reduction (-6 951.1 Pt), whereas functional and technological destructiveness is characterized by the lowest degree (-6 171 Pt each) (Fig. 1).

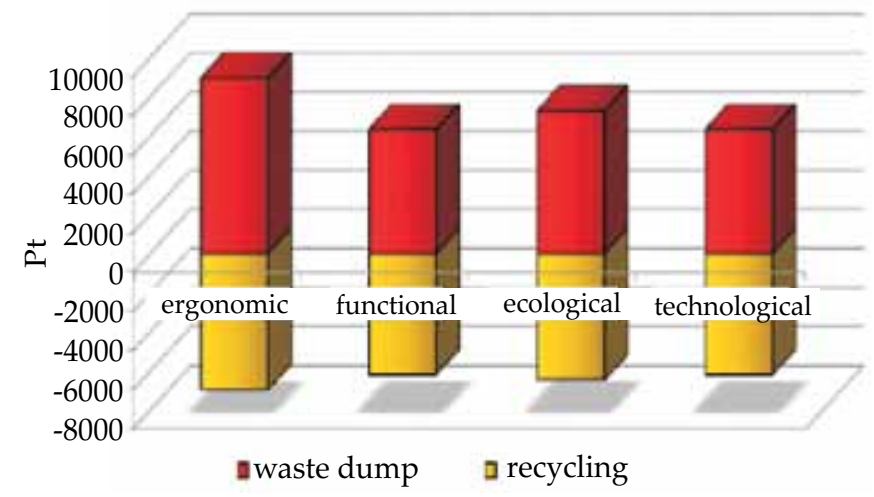

Fig. 1. The impact of Gamesa G90 wind turbine rotor assembly for specific types of destructiveness in relation to disposal models (own work) 


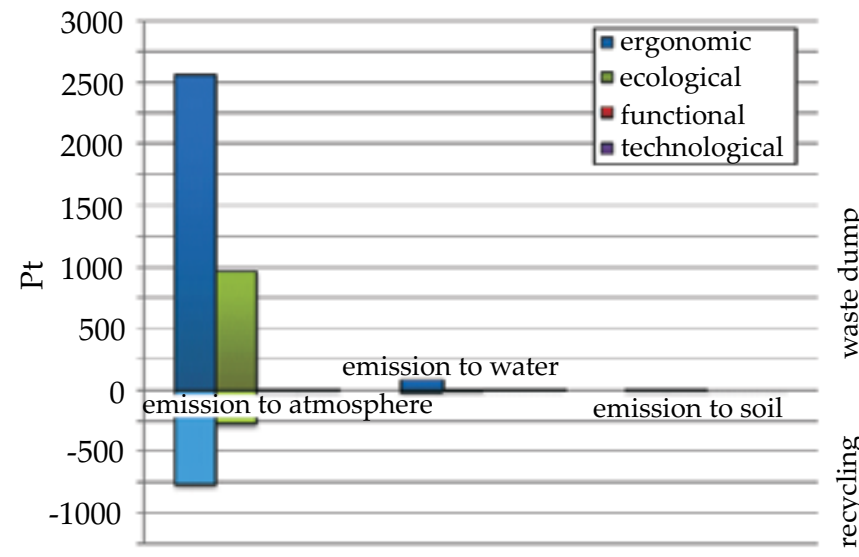

Fig. 2. The impact of the life cycle of Gamesa G90 wind turbine rotor assembly for the types of destructiveness in relation to emission types (own work)

Analyzing the life cycle of rotor plastics blades in relation to emission types, one may note that for waste dump model, emissions to atmosphere account for the highest percentage of the entire share in relation to all the types of destructiveness (total of $3557.569 \mathrm{Pt}$ ). Emissions to soil account for the lowest percentage (total of $4.538 \mathrm{Pt}$ ), assuming the maximum also for ergonomic destructiveness $(2.3 \mathrm{Pt})$, but they do not reach significant values for functional and environmental destructiveness. The highest total emission is recorded for ergonomic destructiveness (2 $649.978 \mathrm{Pt})$, whereas the lowest for functional and technological destructivenesses (14.921 Pt each). For recycling model, emissions to atmosphere account for the highest percentage of the entire share in relation to all the types of destructiveness (total of $-1041.63 \mathrm{Pt}$ ). Emissions to soil account for the lowest percentage. The highest reduction of the total emission is recorded for ergonomic destructiveness $(-780.13 \mathrm{Pt})$, but it does not reach significant values for functional and technological destructiveness (Fig. 2).

Figure 3 shows the impact of the life cycle of rotor blades for the types of destructiveness in relation to polymers and materials. In the case of disposal to a waste dump, the level of harmful impact caused by polymers is particularly high in all four types of destructiveness (total of $23495.078 \mathrm{Pt}$ ), whereas the one caused by groups of other plastics and materials is particularly low (total of $123.323 \mathrm{Pt}$ ). Ergonomic destructiveness is characterized by the most harmful impact (total of $9176.864 \mathrm{Pt}$ ). Functional destructiveness and technological destructiveness demonstrate the lowest impact (6 539.022 Pt each). However, for recycling model, the reduction of harmful impact caused by polymers is particularly high (total of $-22519.67 \mathrm{Pt}$ ), whereas there is no reduction of harmful impact caused by the group of other plastics and materials. Ergonomic destructiveness is characterized by the highest reduction of harmful impact (total of $-6722.63 \mathrm{Pt}$ ); the lowest is demonstrated by functional destructiveness and technological destructiveness (-5 954.01 Pt each).

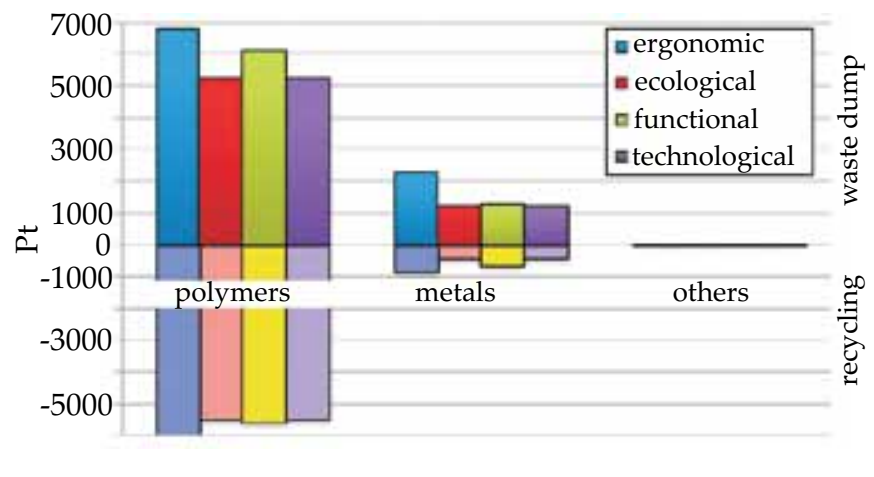

Fig. 3. The impact of the life cycle of Gamesa G90 wind turbine rotor assembly for the types of destructiveness in relation to plastics and materials (own work)

\section{CONCLUSIONS}

The study resulted in testing and assessment procedure for destructiveness of the life cycle of Gamesa G90 wind power rotor blades. The achieved goal embraced ergonomic, functional, ecological and technological destructiveness.

When it comes to ergonomic destructiveness, inorganic compounds causing respiratory diseases were characterized by the highest level of harmful impact (0.0863 DALY); for functional destructiveness it was land use (3 $\left.013.526 \mathrm{PDF} \cdot \mathrm{m}^{2} / \mathrm{a}\right)$; for ecological destructiveness - compounds causing climate change (0.0204 DALY); and for technological destructiveness - land use (3 $013.526 \mathrm{PDF} \cdot \mathrm{m}^{2} / \mathrm{a}$ ). For disposal in the form of recycling, the best results in terms of reduction of harmful impact were obtained in the processes related to fossil fuels extraction in relation to all four types of destructiveness $\left(-2.56 \cdot 10^{5} \mathrm{MJ}\right.$ each).

Taking into account the total impact of the life cycle of rotor plastics blades in grouping and weighing model for the types of destructiveness, one may note that ergonomic destructiveness demonstrated the highest level of harmful impact of disposal to a waste dump (8 $962.347 \mathrm{Pt}$ ), whereas the lowest level was obtained for functional destructiveness and technological destructiveness (6 $327.289 \mathrm{Pt}$ each). The highest level of harmful impact reduction for the recycling model was demonstrated by ergonomic destructiveness (-6 951.1 Pt), while the lowest by functional destructiveness and environmental destructiveness (-6 171 Pt each).

As for the life cycle impact in relation to emission types, one may note that for waste dump model, emissions to atmosphere accounted for the highest percentage of the entire share in relation to all the types of destructiveness (total of $3557.569 \mathrm{Pt}$ ), reaching maximum when it comes to ergonomic destructiveness (2 559.622 Pt). Emissions to soil, on the other hand, accounted for the lowest percentage (total of $4.538 \mathrm{Pt}$ ). 
In the case of disposal of plastics and materials to a waste dump, the level of harmful impact caused by polymers was particularly high in all four categories of destructiveness (total of $23495.078 \mathrm{Pt}$ ), whereas the one caused by groups of other plastics and materials was particularly low (total of $123.323 \mathrm{Pt}$ ). Ergonomic destructiveness was characterized by the most harmful impact (total of $9176.864 \mathrm{Pt}$ ), which reached maximum for polymers (6 833.529 Pt). Functional destructiveness and technological destructiveness demonstrated the lowest impact (6 539.022 Pt each).

The increasing degradation of environment and continuous depletion of its natural resources have led to the bigger interest in the issues of protecting, shaping, and above all - improving the environment. So far, elimination of harmful effects related to human activity has been the main focus; modern science, however, is more inclined to eliminate hazards at their very source. Efficiency of these actions is contingent upon thorough identification, description and improvement of mechanisms within technical facilities that have destructive impact at all stages of their life cycle.

\section{REFERENCES}

[1] Piasecka I.: Inżynieria i Aparatura Chemiczna 2014, No. 2, 103, ISSN: 0368-0827.

[2] Mroziński A., Piasecka I.: Polish Maritime Research 2005, 22, 86. http://dx.doi.org/10.1515/pomr-2015-0021

[3] Brøndsted P., Lilholt H., Lystrup A.: Annual Review of Materials Research 2005, 35, 505.

h t t p://dx.doi.org/10.1146/a n nurev. matsci.35.100303.110641

[4] Cherrington R., Goodship V., Meredith J. et al:: Energy Policy 2012, 47, 13. http://dx.doi.org/10.1016/j.enpol.2012.03.076

[5] Beauson J., Madsen B., Toncelli C. et al.: Composites Part A: Applied Science and Manufacturing 2016, 90, 390. http://dx.doi.org/10.1016/j.compositesa.2016.07.009

[6] Liu P., Barlow C.Y.: Waste Management 2017, 62, 229. http://dx.doi.org/10.1016/j.wasman.2017.02.007

[7] Piasecka I.: Ekologia i Technika 2013, No. 1, 33, ISSN: 1230-462x.

[8] Flizikowski J.B.: „Rozprawa o konstrukcji”, Wydawnictwo i Zakład Poligrafii Instytutu Technologii Eksploatacji, Bydgoszcz-Radom 2002, ISBN: 83-7204-280-2.

[9] Powierża L.: „Zarys inżynierii systemów bioagrotechnicznych", Wydawnictwo i Zakład Poligrafii Instytutu Technologii Eksploatacji, Radom-Płock 1997, ISBN: 83-87039-32-2.

[10] Steller R., Kędziora G., Mitchener G. et al.: Polimery 2017, 62, 181. http://dx.doi.org/10.14314/polimery.2017.181

[11] Kłos Z., Kurczewski P., Kasprzak J.: „Środowiskowe charakteryzowanie maszyn i urządzeń", Wydawnictwo Politechniki Poznańskiej, Poznań 2005, ISBN: 8371433867.

[12] Treloar G.J., Love E.D., Faniran O.O., Iyer-Raniga U.: Construction Management \& Economics 2000, 18, 5. http://dx.doi.org/10.1080/014461900370898

[13] Georgakellos D.A.: Journal of Cleaner Production 2005, 13, 567. http://dx.doi.org/10.1016/j.jclepro.2003.12.020

[14] May J.R., Brennan D.J.: The International Journal of Life Cycle Assessment 2003, 22, 215. http://dx.doi.org/10.1007/BF02978474

[15] "Handbook on Life Cycle Assessment. Operational Guide to the ISO Standards" (Ed. Guinée J.B.), Springer Science + Business Media B.V., 2002, ISBN: 978-0-306-48055-3.

[16] Klinglmair M., Sala S., Brandão M.: The International Journal of Life Cycle Assessment 2014, 19, 580. http://dx.doi.org/10.1007/s11367-013-0650-9

[17] Dreyer L.C., Niemann A.L., Hauschild M.Z.: The International Journal of Life Cycle Assessment 2003, 8, 191. http://dx.doi.org/10.1007/BF02978471

[18] Guinée J.B., Heijungs R., Huppes G. et al.: Environmental Science and Technology 2011, 45, 90. http://dx.doi.org/10.1021/es101316v

Received 17 VII 2017 